\title{
The Austrian Andreas Reischek's Ornithological Exploration and Collecting in New Zealand 1877-1889
}

\section{K.E. WESTERSKOV}

Andreas Reischek was one of four central European scientists and naturalists who contributed substantially to the study and taxonomic clarification of the New Zealand bird fauna a century or more ago; the other three were Ernst Dieffenbach (1811-55) in New Zealand during 1839-41, Ferdinand von Hochstetter (1829-84), in New Zealand with the Austrian Novara Expedition 185859, and Julius von Haast, in New Zealand from 1858 until his death in 1885 . These three were of German birth although Hochstetter spent his working life after New Zealand as professor of mineralogy and geography and director of the Hofmuseum in Vienna.

Reischek was Austrian by birth and of the four the one who in his life-time received the least recognition and the fewest honours; posterity may judge him differently as his collection and publications are becoming known. He was born in humble circumstances, and did not benefit from good schooling and university studies in contrast to the three Germans whose names are indelibly connected with scientific exploration in colonial New Zealand.

Early Life

Andreas Reischek was born on 15 September 1845 as son of Finanzoberaufseher (collector of shipping fees) Andreas Reischek and wife Barbara, born Danzer. His birthplace was in Linz, provincial capital of Oberösterreich. His mother died shortly after his birth from child-birth fever and he was nursed and raised by a foster-mother, Frau Buchrucker, the widow of the gardener of the castle Weinberg at Kefermarkt, north-east of Linz.

In a search for sources of Reischek's deep interest in nature we find first that his grandfather was a forester from Schüttenhofen and although his father was now city-based, he early awakened the child's curiosity for the secrets of nature (Reischek, 1951). In the castle "verlebte er mit den Söhnen des Arztes und Oberförsters in einer herrlichen Umgebung glückliche Kinderjahre. Das stattliche Schloß, noch mit Ringmauern und Graben umgeben, prächtige Sammlungen an Waffen und Naturalien, welche der Graf, ein weit gereister Mann, angelegt hatte, die Gewächshäuser mit seltenen, fremdartigen Blumen, das Tier- und Pflanzenleben in Wald und Feld, alles wirke auf die erregbare 
und feurige Phantasie des Knaben lebhaft ein, dazu die Erzählungen seines Vaters von seinem Großvater, einem weidgerechten Jäger und Naturfreunde, kurz, der lebhafte Knabe wollte ein Jäger werden, hinaus in die Ferne ziehen, noch weit hinter die blauenden Alpengipfel, die man von den Bergen der Heimat im fernen Süden sieht, er wollte fremde Länder und Menschen kennen lernen, wie Cook und Tasman, deren Reisen ihm in die Hände fielen". (Commenda, 1902).

From the village school at Kefermarkt, Reischek when eight years old was taken back to Linz by his father and sent to the Normalschule (ordinary state school) in Linz (Wettstein, 1957). The father's meagre income did not, unfortunately, allow the gifted youngster to go on to Gymnasium and university and he had to learn a trade. The choice was a lucky one, not so much for the specific trade as for the qualities of his particular master. Reischek was apprenticed to a Herr Danner, master baker in Unterweißenbach, and here he learned not only baking (which must have stood him in good stead during his later month-long travels in the New Zealand bush) but was also taken hunting with the baker and his son. It was also during this period of his youth that Reischek learned taxidermy (Musil, 1962).

His apprenticeship in the baker trade lasted from 30 May 1860 to 21 January 1866 , but he had hardly qualified when he was called up. He joined the Imperial 26. Feldjäger-Bataillon and after a short training saw service in Italy in 1866 against the Garibaldians, entitling him to wear the Kriegermedaille (Reischek, 1951). During this period he became well acquainted with his captain, Freiherr Gotter von Reste-Ferrari and entered into his service; after the campaign he became the Leibjäger of Baron Pasetti with whom Reischek travelled widely in Italy and other countries. Because of Pasetti's interest in hunting and animals generally, Reischek learned much, read much and, preparing hunting trophies for his patron, improved his skills in the craft of taxidermy. Pasetti became military attaché in Rome and during this period Reischek also had the opportunity to attend lectures in ornithology at the university.

In 1875 when thirty years old Reischek married in Vienna Adelheid Hawlicek, having resigned from his military and para-military status. According to his son (Reischek, 1951, p. 9) Reischek had served as Jäger with his bataillon and remained on its roll for ten years, one month and twenty five days, but there seems to be an inconsistency here as, according to the same source, he had finished his baker's apprenticeship and become a Geselle on 21 January 1866, indicating a somewhat shorter military service.

Married in Vienna, Reischek opened a business of taxidermy and sale of Naturalien and teaching and laboratory material for schools and collections, obtaining much material from hunting (Commenda, 1902).

Reischek's abilities as a taxidermist attracted attention and thus gave rise to his acquaintance with the Kustos of the Imperial Museum of Natural History in Vienna, Hofrat Dr A. Steindachner (later director). The present stately Museum 
was just then in the process of being built, with professor (later director) Ferdinand von Hochstetter as superintendent. Hochstetter was a geologist with a wide interest in natural history. As a young man (in 1858-59) he had spent nine months in New Zealand, and it so happened that his arrival with the Austrian Novara Expedition coincided with the arrival of the German geologist J.F.H. Haast (later Sir Julius von Haast). Haast had accepted a commission from a firm of English shipowners - Willis, Gann \& Co. - to visit New Zealand and report upon the likely prospects of large-scale German emigration to the Colony; he arrived at Auckland on 21 December 1858, and the next day the Novara anchored and thus Haast and Hochstetter met. This was the beginning of nine months of cooperative endeavour studying geology in New Zealand and the foundation of a life-long friendship (von Haast, 1948). And it is in this situation we find the cause of Reischek's coming to New Zealand.

Haast and Reischek

Haast and Hochstetter together spent nine months of geological studies, field work and comradely discussion, to some extent in an age-wise inverted teacher/student situation: Haast was seven years Hochstetter's senior; the latter was a doctor and university teacher (Privatdozent) from 1856 at the Geological Institute in Vienna. Haast had his interest in geology rekindled by the enthusiastic Hochstetter. Haast had studied mineralogy and geology at the University of Bonn for some years without, however, graduating. After Hochstetter's departure, Haast was appointed to make geological and topographical surveys in Nelson and later in Canterbury; his diligent work (details in his son's biography: von Haast, 1948), evidenced in valuable published reports eventually earned Haast an honorary Dr. phil. degree (1862), an F.R.S. (1867), directorship of the Canterbury Museum (1869), Austrian Knighthood: Ritter Julius von Haast (1874), Professorship of Geology and Palaeontology at Canterbury College (1876), and British Knighthood: Sir Julius von Haast (1886).

Haast's colossal energy resulted in many successful developments. His major contribution was to be the building up of the Canterbury Museum. And it is incredible to read that had it not been for the fact that Haast's taxidermist Fuller, was a heavy drinker and had to be suspended (von Haast, 1948, p. 793), it is doubtful whether Reischek would ever have set foot on New Zealand soil; nor would he have subsequently contributed so much to the study of New Zealand birds and assembled such a large collection of well prepared and well labelled specimens, a rare thing in those days.

The events leading to Reischek's eventual arrival are as follows (according to von Haast jun.): von Haast had been appointed director of the Canterbury Museum in 1869 and spent the following years with building plans and getting collections together from New Zealand as well as from overseas. By mid-1876 Haast had 'a new and formidable worry' as his taxidermist was drinking heavily 


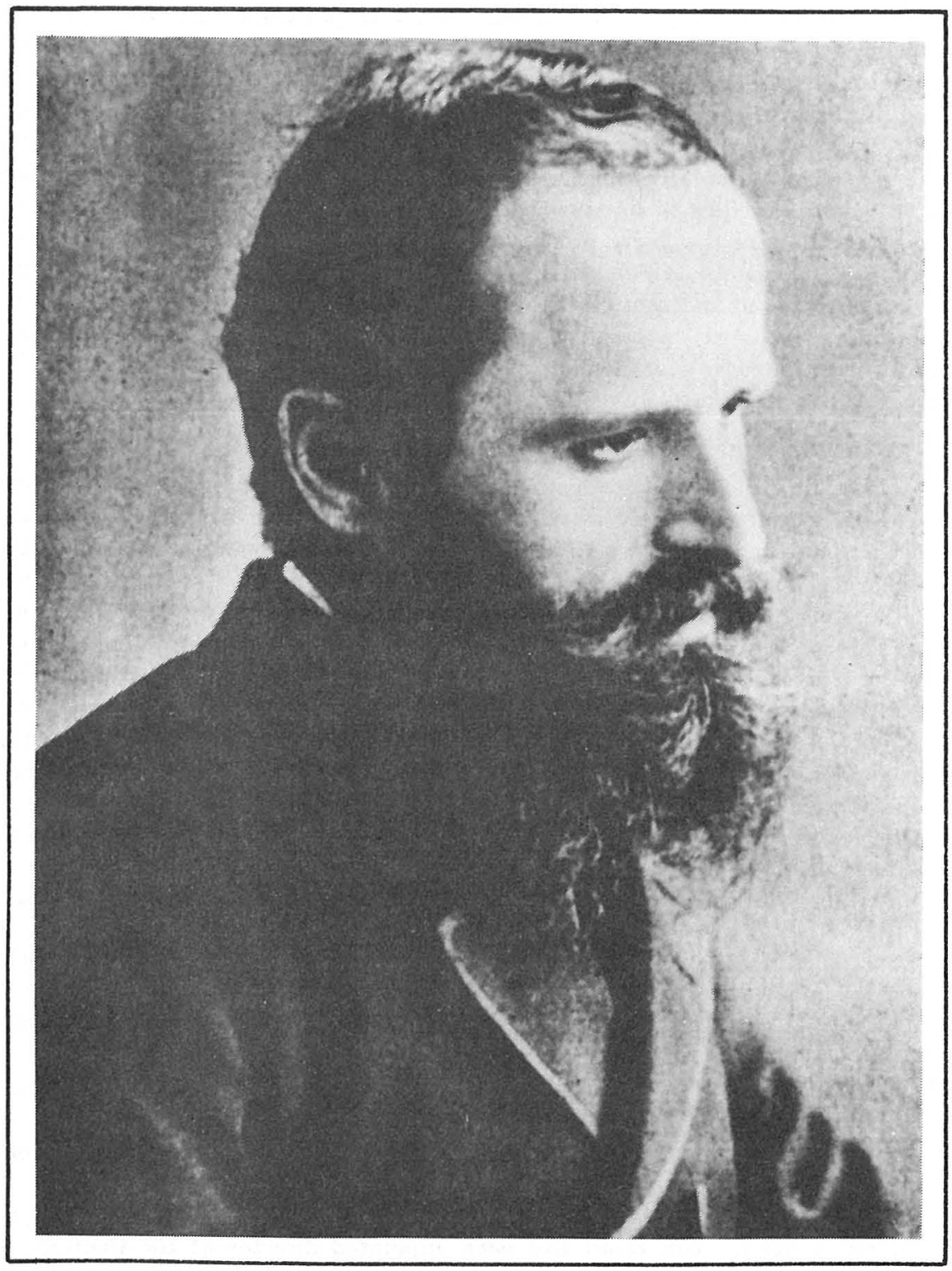

Andreas Reischek photographed c. 1894 when he was forty nine years of age and living at Kefermarkt near Linz (photograph presented by Reischek's grandson, Herr Gerhard Reischek, Linz). 
and had to be suspended by Haast who reported the matter to the Board; on 10 July the Board dismissed Fuller, who subsequently poisoned himself with arsenic.

Bird and mammal specimens and skins arrived constantly, and Haast turned immediately to his old and successful friend, Hochstetter, who had become professor in Vienna in 1860 and newly appointed Intendant (Director-General) of the new Natural History Museum in Vienna. Hochstetter, now a 'museumman' with wide interests (including birds) must have discussed Haast's request for a taxidermist with colleagues and friends, but there seems to be some uncertainty as to how the choice fell on Reischek. Wettstein (1957) wrote that Hochstetter had early become aware of Reischek as a capable taxidermist and asked him if he would travel to New Zealand and arrange the collections in the newly built museum in Christchurch; a similar view was expressed by von Haast (1948, p. 796) but Heger (1902) and later Kerschner (1952) stated that the choice fell on Reischek on the proposal of the ornithologist, Dr. F. Steindachner, later director of the Museum; Steindachner apparently knew Reischek and was aware of his taxidermic skills. Reischek lived in Vienna, had married the year before, and was then thirty one years of age. His son (Reischek, 1952, p. 9) described the situation even more dramatically (although apparently somewhat exaggerated); he said that Hochstetter 'engagierte Reischek als Präparator" (which is not correct; according to the present Director of the Vertebratabteilung, Dr Kurt Bauer, Reischek was never employed at the Natural History Museum in Vienna) and that Hochstetter soon became convinced of Reischek's 'geniale Persönlichkeit' and also of his other attributes as 'gediegener Ornithologe, universeller Kunsthandwerker, virtuoser Mundharmonikaspieler, Komponist und Improvisator von Mundartvierzeilern".

Which ever way it came about, the fact remains that Reischek apparently without delay signed the two-year contract to work with Haast in the Canterbury Museum. His desires for adventure, exploration, seeing foreign lands, travel, bird study and collection, all seemed about to be fulfilled. Married just under two years, he left with the understanding that his Adelheid would have to remain behind at least till he saved enough money to send her the fare to join him; in any case, the appointment was for two years only - as it turned out, Reischek did not return till twelve years later.

\section{Travel to New Zealand}

Reischek left from the Wiener Südbahnhof on 6 February 1877, travelling by train to Trieste where he boarded the Austrian Lloyd steamer Kastor on 11 February. On the first leg of the journey, to Suez, Reischek experienced a violent storm and was severely ill from sea sickness (coughing blood) so that the ship's doctor declared that he was not fit for long and difficult journeys without risk to his health (Buchgraber, 1961). He proceeded to Suez where he transferred to the Nepaul, then through the Suez Canal, only recently completed 
(1869) and via Aden to Ceylon where on 9 March, he transferred to the Bungalore: He journeyed on southwards, through the heat, and complained in his diary (see Reischek, 1952, pp. 13-20) of rats, red ants, a small-pox epidemic, high seas and reached Adelaide and then Melbourne where he left the Bungalore and after a few days stay boarded the small steamer Tangaroa in which he on 20 April reached Port Chalmers. Here he was met by professor F.W. Hutton who took him to Dunedin by rail, gave him lunch and showed him the Otago Museum of which he was the director. Next day he proceeded to Lyttelton, where his future superior, Dr Julius von Haast was waiting for him; it is interesting that Commenda (1902, p. 5) calls it 'Little Town' - could that be after Reischek's diary spelling? And Reischek was finally at the end of his travels, arriving at Christchurch on 22 April 1877, where Haast, museum and plenty of work awaited him. There is some confusion as to Reischek's arrival at Christchurch; several authors, including Wettstein $(1957$, p. 16) have stated that he arrived on 22 May, but this is erroneous and at least some (if not all) of the misunderstanding can be referred back to a misprint (or mistake) in Reischek's son's book Sterbende Welt (1924, p. 34) where he gives the date of 21 May for the day after his arrival in New Zealand (it should have been 21 April). This mistake is not repeated in the English edition (Reischek, 1952).

Reischek's two years in Christchurch

Reischek settled in to hard work and long hours as was the custom in those days. According to Commenda, thirty chests full of skins and skeletons awaited him in the museum, so there was plenty to do. It is equally obvious that Reischek - outdoorsman and hunter as he was - could not long be satisfied stuffing birds indoors. We know he arrived at Christchurch on 22 April 1877 (Wettstein, 1957), and it was surprising to find the first communication of Reischek's from New Zealand (Reischek, 1877), which showed that a note on a captive Kiwi was written and sent from Christchurch on 20 July 1877, or just under three months after his arrival. In this communication to the editor, Dr C. von Enderes, of the Viennese ornithological journal just started in 1877 Mittheilungen des Ornithologischen Vereines in Wien, Reischek tells of a captive Kiwi (he says Apteryx. Owenii and it very likely was Little Spotted Kiwi Apteryx oweni, obtained from the West Coast) which he had obtained 'vor einigen Monaten': this is something of an exaggeration as he had not even been in this country three months when he wrote it; maybe he obtained the bird shortly after his arrival, showing his keenness.

As this short note was his first about New Zealand birds, contains interesting information and shows his powers of observation, it follows below in extenso (translated):

Reischek's tame Kiwi

"A few months ago I received from a friend in Hokitika on the West Coast a live male kiwi; I feed this bird with raw meat cut like worms which I mix with 
earth and green moss, and it is doing quite well on this diet. The bird sleeps during the day in a hole, which I have made for him in the ground; when sleeping he sits on the knee-joints just like the ostrich and holds the head between his legs. He comes forth in the evening when it grows dark, enters the water and wades around, drinks and preens himself; then he starts feeding and drinks again after each morsel he swallows. Every evening I let him wander about my workshop; he then observes everything, examines every nook and peeps into every jar, wanders around the stuffed animals and inspects them and scratches with his feet.

He snaps (knackt) with his beak like an owl and also defends himself with it. When I approach him, he never runs away but takes up a defensive position and tries to scratch; every time he makes a jump, often so violent that he falls on his back, but this does not in the least deter him or cause him to flee. He will return to the attack right away. In his cage he digs holes in the sand and pokes his long bill into the holes.

I am doing my best to obtain a female kiwi, but this is very difficult as these animals have already been exterminated in the settled districts; they now live only on the West Coast where, however, it is only with the expenditure of much time and effort that one or other of the kiwis can be caught. As they fetch high prices, every one wants to catch kiwis, and they will therefore soon disappear completely. My friend has in the meantime promised me several specimens.

I have been offered live Kakapos or Night Parrots (Strigops habroptilus) which likewise have become very rare.

It is my intention if possible to bring live Kakapos and kiwis to Vienna."

Only one editorial comment on the above: Reischek had Hokitiki for Hokitika, a misprint or a mistake? Reischek's power of observation is evident even in this short note: how the kiwi sleeps and its defensive behaviour.

A pair of live Kakapo

In addition to his routine work at the museum, stuffing specimens, making skeletons and organizing the material in the collection, Reischek was active in his spare time observing and collecting birds. He also obtained a pair of Kakapo as alluded to in the kiwi note and wrote a brief note about this then already rare bird (Reischek, 1878); this note was sent on 18 October 1877:

"I have at present two live Kakapo, a male and a female, which I feed with raw potatoes, carrots and bread soaked in milk and water, and they appear to do quite well on this food. During the day they sit and sleep with the head behind the wing or between the legs; they don't become active till towards evening. Their movements are somewhat clumsy and yet quick, and they run, climb and dig very fast. When digging they first loosen the soil with their feet and then pull it out of the hole with their beak. They relieve one another at this work after a while; while one is digging, the other rests and so on alter- 


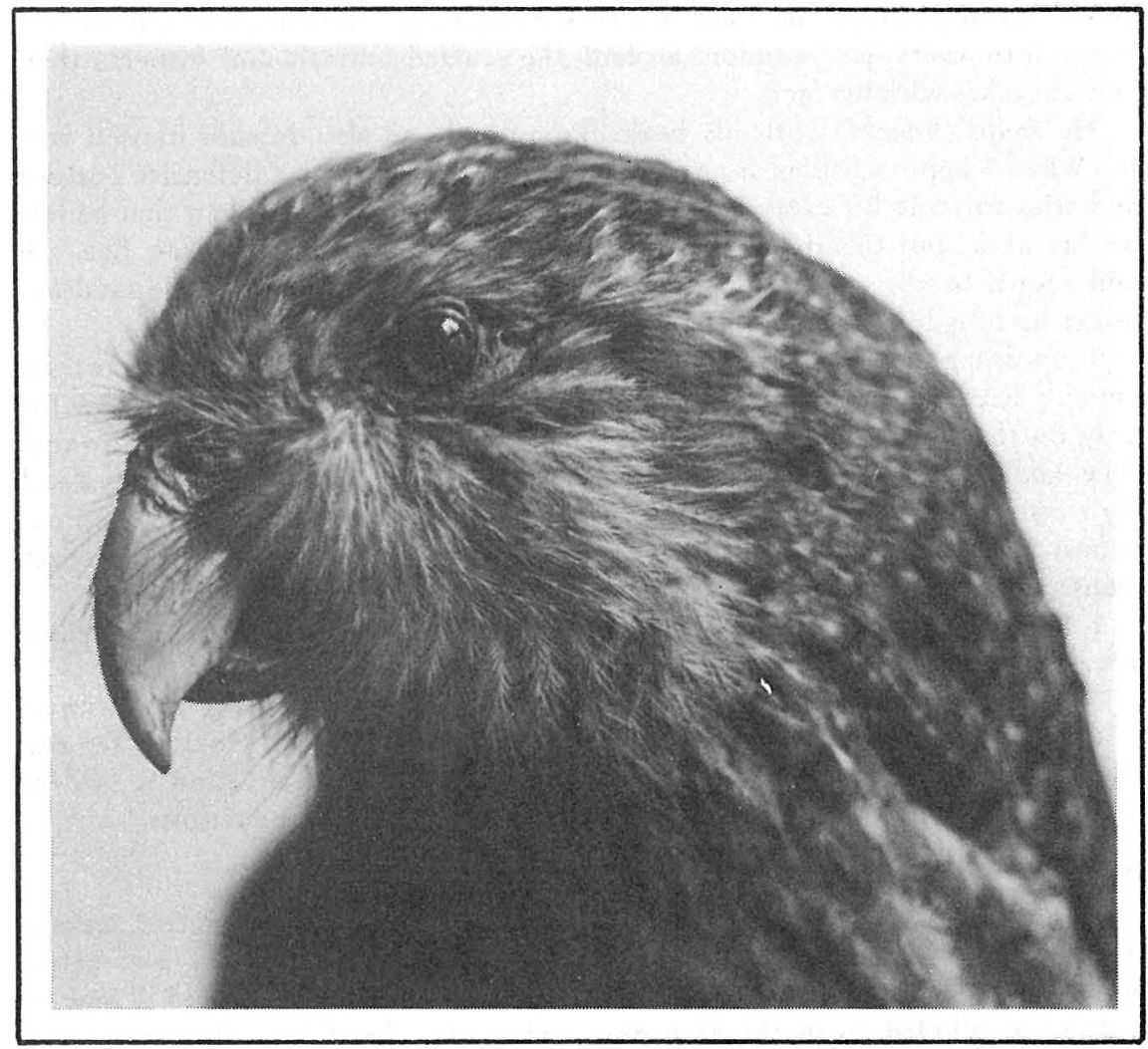

Reischek was an excellent taxidermist, capable of giving his specimens a life-like appearance as in this Kakapo from a display case in the Öberösterreichische Landesmuseum Linz. 
nating. The holes dug out by the Kakapo measure on average six inches (= about $16 \mathrm{~cm})$ across, have a depth of about $1 \frac{1}{2}$ feet $(=47 \mathrm{~cm})$ and are used by the animals during the day as sleeping quarters. I never saw my Night Parrots fly.

Now and then they had a fight; then they made sounds which sound very much like the scream of a hare; during fights they never use their bill but only their feet and make - as can easily be imagined - the most peculiar and funny leaps. The weaker of the two regularly lies down during the fight and defends itself against the stronger mate with its feet.

Both birds are quite tame but never show any attachment to me.

It is a pity that these interesting animals already are so rare and soon will be exterminated.

I received my Kakapo as well as the kiwi from the West Coast. Older birds never last for long in captivity, but my pair is only a year old, so I hope that I shall be successful in bringing the birds to Vienna alive.

As I spend every Sunday in the forests or at lakes and estuaries I have rich opportunity to make many and varied observations and studies. As an example I can mention that my dog a couple of weeks ago brought me two half-grown and live Wekas (Maorihïhner) about which I shall tell you at some later date".

Reischek used the old name Ocydromus australis for Weka, now called Gallirallus australis.

Expeditions in New Zealand

Reischek had been engaged for two years at a salary of $£ 220$ (von Haast, 1948 , p. 796) to work as a taxidermist at the Canterbury Museum where till this day many display specimens bear witness to his skill. In addition to Sunday outings around Christchurch when he collected a number of birds now in the Vienna Museum he also managed two longer expeditions to the hinterland. These and later travels are well described (and well known) from his son's narrative (Reischek, 1930, latest edition 1952) based on the father's published accounts and diaries and will not be discussed here except in brief outline. The English translation and editing (by H.E.L. Priday) does not compare with the much more detailed account presented in the original German editions (Reischek 1924, the re-written account: 1948), but Yesterdays in Maoriland served the purpose of bringing Reischek's contribution into focus at a time (in Austria as in New Zealand) when he was largely forgotten. In the following review of his expeditions, references will be made to the accounts in this English edition.

It is difficult to enumerate Reischek's major expeditions, as it will always be a matter of judgement how to limit or combine individual journeys. I propose to summarise his activities in the form of ten expeditions, even if in some cases (as Little Barrier Island) several individual trips were made.

(1) Reischek's first expedition was a solo trip on horseback, 18 December 1877 - 23 January 1878 from Christchurch to Porter's Pass, Waimakariri 
River, Arthur's Pass, Otira Gorge, Taramakau Valley, Lake Brunner, Haihuna Plain, Mount Alexander and return via Arthur's Pass (Reischek, 1952, pp. 21-40).

(2) The second expedition was in the company of $\mathrm{Dr}$ J. von Haast, his superior 27 February - 14 March 1879 from Christchurch to Windwhistle, Rakaia Fork, Mount Algidus, Rakaia, Whitcombe Pass (Haast named a new-found glacier Reischek Glacier), Rose Glacier, Whitcombe River and return (Reischek, 1952, pp. 44-56).

(3) Leaving Christchurch in July 1879 , Reischek sailed to Kaipara Harbour, later travelled on to Auckland; 1 September 1879 - end of April 1880 travelled widely in Northland: Kaipara, Aratapu, Paparoa, Waipu, Waitakare Range, and on to Thames, Coromandel (Reischek, 1952, pp. 68-82).

(4) In his search for the rare Stitchbird Notiomystis cincta he set out six times and was able to land on Little Barrier Island four times: October 1880, June 1882, December 1883 and April 1885 (Reischek, 1952, pp. 83-93, see also Reischek, 1885a and 1886).

(5) Island expeditions off Northland: Taranga Island, October 1880, January - February 1882, May 1883, April 1884; Hen and Chickens, May and December 1880, May 1883; Kawau Island, January 1882; Great Barrier Island, March 1882; Guano Island, November 1883; Karewa Island, February 1885 (Reischek, 1952, pp. 94-112; some of the dates are from specimen labels, Naturhistorisches Museum Wien; on the Hen and Chickens Reischek found Little Shearwater Puffinus assimilis nesting, new for the New Zealand list but not the description of a new species as subsequently occasionally referred to, see also Reischek $1885 \mathrm{~b}$; on the Hen and Chickens see Reischek, 1881).

(6) Travels in the King Country in 1882, then still closed to pakehas, but with special permission (Reischek, 1952, pp, 148-196).

(7) Expedition to the Fiordland sounds, in particular Dusky Sound, April October 1884 (Reischek, 1952, pp. 231-246; on Dusky Sound see also Reischek, 1884).

(8) Expedition to Chalky Sound, Fiordland, January - June 1887, then to Paringa Bay, staying till January 1888; much bird collecting (Reischek, 1952, pp. 248-268; on this stay at Chalky Sound see also Reischek, 1887).

(9) Expedition to southern and sub-antarctic islands, with the government steamer Stella; to Stewart, Snares, Auckland, Campbell, Antipodes and Bounty Islands January - February 1888 (Reischek, 1952, pp. 269-284, also Reischek, 1888a and b). 
(10) Reischek's last expedition was the ascent of Ruapehu (2797 m), starting from Wanganui to Tokaanu, Taupo, Kaingaroa, Rotorua, Matamata and Auckland May - June 1888 (Reischek, 1952, pp. 285-304).

Ornithological publications

Reischek wrote and published a number of papers in English and German on his studies of New Zealand birds. His papers in English were all published in the then only available avenue in this country, the Transactions of the New Zealand Institute. In all he published sixteen shorter and longer papers this way, between 1881 and 1888 (thus all while he was here); examples of these are the short monographic types of papers, such as on the Stitchbird (Reischek, 1885a) and Little Shearwater (Reischek, 1885b), and longer papers describing the bird life of an area such as Dusky Sound (Reischek, 1884).

His papers in German were till recently unknown and unused in New Zealand. They were found during stays in Vienna in April - May 1978 and January February 1980. Most of these papers were published in an old, local and long defunct journal Mittheilungen des Ornithologischen Vereines in Wien. Some of them overlapped to some extent with Reischek's papers in English, others were quite distinct and contained much hitherto unavailable information, in particular with regard to former distribution of rare and now extinct species. It is intended to translate and publish the more important of these papers with appropriate comments and evaluation; the first of this series, on the Kokako Callaeas cinerea has been published (Westerskov, 1979) and others will follow. After his return to Austria, Reischek read a paper (Reischek, 1891) on the decline of the New Zealand avifauna as influenced by colonization to the Zoological-Botanical Society in Vienna, an important paper also in the process of publication in translation.

The book about Reischek's dog Caesar

The only publication by Reischek in book-form, a small volume, written in English, is his Caesar: The Wonderful Dog, published in Auckland 1889, at the price of one shilling. In addition to being a biography of his faithful and useful dog, Caesar, it also contains - as the sub-title reads - 'Some Notes on the Training of Dogs and Horses. Also Hints on Camping, Bush and Mountain Exploration in New Zealand'. It is: 'Dedicated to the People of New Zealand'. This is an intriguing book for lovers of dogs and for any one interested in life in early New Zealand. There are many references to birds. The book was translated by his son and published as A. Reischek: Caesar, der Freund des Neuseelandsforschers (Wien, 1928).

Reischek's New Zealand bird collection in Vienna

Probably Reischek's major contribution was his almost complete collection (900 specimens plus a number in display cases) of the New Zealand bird fauna. 
Even while employed as the taxidermist at the Canterbury Museum, he collected and skinned birds for the purpose of bringing back to Austria a representative if not complete collection of New Zealand birds.

The specimens are well preserved and well labelled, using Reischek's personal (printed) labels, containing the specimen's scientific name, sex, age (as known), locality, whether in North or South Island, month and year. The collection contains practically all species that could be expected - with two or three (mysterious) omissions, such as Great Spotted Kiwi Apteryx haasti (described from Westland by Potts in 1872) Black-fronted Tern Sterna albostriata and Rock Wren Xenicus gilviventris.

There are valuable series collected by Reischek of now extinct or very rare birds such as eighteen Kakapo Strigops habroptilus, also two small downy chicks and three eggs; two Laughing Owl Sceloglaux albifacies and two eggs; eight Bush Wren Xenicus longipes and one egg; thirteen Stitchbird, also a nest and one egg; eight Huia Heteralocha acutirostris; fourteen Kokako and a nest and chick; twenty two New Zealand Thrush Turnagra capensis and a nest and one egg. A review of this collection is in preparation.

Reischek's last years in Linz

Reischek's original two year contract with von Haast was followed by another ten years of collecting birds, studies, exploration, interspersed with work at the museums in Auckland and Wanganui to earn money to finance further travel. Eventually he must have felt that the collections of birds and Maori artefacts (a subject outside the scope of this paper) and his studies were complete. He had been made an F.L.S. (in May 1885) in recognition of his scientific endeavours in New Zealand, and the Auckland Institute (of the New Zealand Institute) presented him with an address at the last meeting he attended (18 February 1889) before his departure on 20 February. This address recorded the appreciation of the Council and members of "the valuable services rendered to the cause of Science in New Zealand by Mr A. Reischek, who has spent twelve years of unwearying and enthusiastic devotion in studying the Natural History and particularly the Ornithology of the Colony" and finishing with "This Institute wishes $\mathrm{Mr}$ Reischek the success and recognition in Europe which his arduous and valuable researches in New Zealand so well deserve". (Reischek, 1952, p. 305).

He arrived home again at the Wiener Südbahnhof on 15 April 1889, finding his wife awaiting him on the platform. But as Kerschner expressed it (1952, p. 147): "Wie aber sollte er sich durchsetzen, er, der zurückhaltende bescheidene Mann, in Neu-Seeland geehrt und nun nach 12 Jahren ein Unbekannter in der Heimat?"

It would appear that Reischek had hopes (and one would think reasonably so) of finding employment in the now completed $k$. $k$. Naturhistorische Hofmuseum Wien; but that was not to be the case. It was some time (two years) 
after his return before his large collection of bird skins (and other material) was obtained for a comparatively modest sum by a group of high-ranking and influential friends and patrons and in 1891 was presented to the Museum; the leader of this group, whose name appears as donor on the specimen labels, was Generalrat Karl von Auspitz. Reischek apparently took these disappointments calmly. He organised the collection and prepared the kiwis and Kakapos in their display-cases (still on show in the Museum). He first lived at Klosterneuburg near Vienna where his only child, Andreas, was born in 1892; in 1894 he moved to Kefermarkt near Linz, and was in 1896 appointed as Kustos to the newly completed Museum Francisco-Carolinum in Linz, now known as the Oberösterreichische Landesmuseum Linz. His contribution to the development of this museum is described by Museum Director, Dr Theodor Kerschner (1933), who paid this tribute after his death: "Für Reischek konnte kein Ersatz gefunden werden".

In 1898 Reischek bought an idyllic house in Römerstraße 96 on the Römerberg slopes of Linz, bordering the Danube. Here he lived the few remaining years of his life; an interesting picture of him at work and at home is given by Guggenberger (1958). His energy and devotion to the task in hand were the outstanding characteristics of a man whose misfortune it was to be born to humble parents in a provincial town. If he had received adequate schooling and university training, Reischek, faced with the same experience would undoubtedly have contributed at a higher scholarly level of publication than was the case.

Subsequent evaluations, in particular Kerschner's (1952) sober tribute to Reischek Zum 50. Todestag presents a factual and fair appreciation of Reischek as a hunter and naturalist, as an ornithologist and collector, as a conservationist, an ethnologist and finally as a 'museum man'.

Reischek's life of - in Sir Julius von Haast's words (von Haast, 1948, p. 799) - "appalling labours and privations, voluntarily undergone" had affected his health, and he died of a heart disease on 3-April 1902, at only fifty seven years of age.

His large and well-documented collection of New Zealand birds will always remain one of the best and most useful bird collections from this country. In future this collection will be of increasing value to New Zealand ornithologists with a serious interest in taxonomic questions. His field observations in a number of publications and also used in Buller's second edition of $A$ History of the Birds of New Zealand (1888) add valuable life-history data on a number of our birds, especially those now rare or extinct.

\section{References}

Buchgraber, V., Von Prinz Eugen bis K. Renner - Österreichische Lebensbilder aus drei Jahrhunderten, Graz, Wien, Köln 1961, pp. 199-207.

Buller, W.L., A History of the Birds of New Zealand, 2nd ed., I \& II, London 1888. 
Commenda, H., "Nachruf", Jahresberichte des Vereines für Naturkunde. 31 (1902), pp. 1-11.

Guggenberger, E., "Meine Erinnerungen an Andreas Reischek", Jahrbuch des Oberösterreichischen Musealvereins 103 (1958), pp. 125-129.

Haast, H.F. von, The Life and Times of Sir Julius von Haast, Wellington 1948. Heger, F., "Nekrolog. Andreas Reischek", Mitteilungen der Anthropologischen Gesellschaft in Wien 32 (1902), pp. 400-410.

Kerschner, Th., "Die zoologischen Sammlungen. 1891 bis 1901. (Unter Andreas Reischek)", Jahrbuch des Oberösterreichischen Musealvereines 85 (1933), pp. 449-454.

- "Andreas Reischek. Zum 50. Todestag am 3. April 1952", Oberösterreichische Heimatblätter 6 (1952) pp. 146-155.

Musil, J., "In Kefermarkt wuchs ein großer Mann auf", Mühlviertler Nachrichten, 12 April 1962.

Reischek, A., "Ein gefangener Kiwi (Apteryx Owenii, Gould)", Mittheilungen des Ornithologischen Vereines in Wien 1, 10 (1877), p. 71.

- "Kakapos oder Nachtpapageien (Strigops habroptilus) in der Gefangenschaft", Mittheilungen des Ornithologischen Vereines in Wien 2, (1878), p. 10-11.

- "Notes on zoological researches made on the Chicken Islands, East Coast of the North Island", Trans. N.Z. Inst. 14 (1881), pp. 274-277.

- "Notes on New Zealand ornithology", Trans. N.Z. Inst. 17 (1884), pp. 187 197.

- a. "Notes on New Zealand Ornithology: Observations on Pogonornis cincta (Dubus); Stitch-bird (Tiora)", Trans. N.Z. Inst. 18 (1885), pp. 84-87. - b. "Observations on Puffinus assimilis (Gould), Totorore, their habits and habitats", Trans. N.Z. Inst. 18 (1885), pp. 95-96.

- "Description of the Little Barrier Island, the birds which inhabit it, and the locality as a protection to them", Trans. N.Z. Inst. 19 (1886), pp. 181184.

- "Recent explorations north of Chalky Sound, West Coast of Otago", Trans. N.Z. Inst. 20 (1887), p. 440, pl. 22.

- a. "The habits and home of the Wandering Albatross", Trans. N.Z. Inst. 21 (1888), pp. 126-128.

- b. "Notes on the islands to the south of New Zealand", Trans. N.Z. Inst. 21 (1888), pp. 378-389.

- Caesar: The Wonderful Dog, Auckland 1889. 
- Sterbende Welt. Zwölf Jahre Forschungsleben auf Neuseeland, Leipzig 1924.

- Yesterdays in Maoriland, Christchurch 1930.

- Ihaka Reiheke - der Maorihäuptling aus Österreich, Wien 1948.

- "Ein Leben für die Heimat", Jahrbuch der Stadt Linz 1951, pp. 6-15. Westerskov, K.E., "Reischek's observations of kokako during his travels in New Zealand 1877-1889", Forest and Bird 13, 3 (1979), pp. 7-12.

Wettstein, O., "Andreas Reischek als Museumsfachmann und Forschungsreisender in Neuseeland" in Österreichische Naturforscher, Ärzte und Techniker, Wien 1957 pp. 15-17. 